\title{
The Influence of Environment on Tourist Satisfaction Seeing from Management, Linguistics and Social Cultural Aspects
}

\author{
Ni Wayan Sitiari ${ }^{1}$, I Gde Suranaya Pandit ${ }^{2}$, A. A. Rai Sita laksmi ${ }^{3}$, \\ I Wayan Budiarta ${ }^{4}$ and Luh Putu Sudini ${ }^{5}$ \\ \{setia_dari@yahoo.co.id ${ }^{1}$, suranaya_pandit@yahoo.com², sitalaksmi08@gmail.com³ \\ budy4rt4762gmail.com ${ }^{4}$ and sudini putu@yahoo.co.id $\left.{ }^{5}\right\}$ \\ Universitas Warmadewa, Denpasar-Bali, Indonesia
}

\begin{abstract}
Customer satisfaction is the center for managers' attention to increase customer loyalty. In this study, we explore the roles of physical and non-physical environment on tourist satisfaction. The analysis technique used is multiple linear analysis techniques. The results show that the effect of the physical environment on tourist satisfaction has a positive effect of 0.653 , and is significant at the 0.05 level. This means that the better the physical environment, the more satisfaction of tourists. The influence of non-physical environment on positive tourist satisfaction is 0.096 but not significant. This means that the better the non-physical environment, the tourist satisfaction will increase but not significant. The physical environment has more influence on tourist satisfaction and is reflected most strongly by the indicators of the type of sea attractions provided and transportation facilities. Tourist satisfaction can be improved if the physical environment is more enhanced than non-physical environment.
\end{abstract}

Keywords: Non-physical environment; physical environment; tourist satisfaction

\section{Introduction}

Tourism has repeatedly been reported as a powerful activity that can have significant impacts on the nation's life, often concerning a country's economy, society and culture, and environment [1]. Culture and tourism have always been inextricably linked to each other [2]. Tourism is a sector with significant economic relevance in several countries [3]. Tourists being consumers would prefer to visit a certain destination where they believe they can easily derive satisfaction without much effort [4]. The senior population is of interest to the tourism industry because of its growing size and increasing participation in travel activities [5].

Tourism contributes enormously towards the economic development of host countries [6]. Sustainable development is increasingly becoming a priority issue in tourism development in the modern world [7]. In its progress, tourism world has shown sustainable growth over the last few decades, leading to the development of multiple tourism-related industries throughout Bali[8]. The anticipated experience is marked by the ways in which ecotourism companies employ ecotourism ideology for their marketing, and the lived experience is marked by tourists after their interaction with the place (landscape) [9]

Tourism is the main source of income for people in Bali. Almost all districts in Bali have tourist destinations. Karangasem, one of the districts located in the East of Bali Province also has some very interesting areas. Unfortunately, it's tourism development has not been able to 
compete with other Regencies in Bali. The district, however, has various most potential cultural tourism areas, including beaches. One of the famous beaches is Candi dasa beach. Other most naturally potential beaches beside Candi dasa are Tulamben beach and Amed Beach.

Physical environmental factors are the environment around the area of tourism. Physical environmental factors in Amed tourism environment are hotels, restaurants, tourism products, transportation facilities, cleanliness, and site location arrangement. Non-physical environment is the cultural aspects and human resource capabilities. The cultural aspect is culture in the form of values. Bali has 66 cultural elements in physical form and values [10]. Culture in the form of values determines attitudes and behavior. Sitiari et al. (2016) found values in the concept of jengah taksu, and menyamabraya (brotherhood) is valid and reliable values that reflect local Balinese culture [11]. Meanwhile, the ability of HR is reflected by the ability to communicate. Based on the results of research on tourist attraction, natural tourism (natural attraction), tourism attractions (building attraction), cultural tourism attractions (cultural attraction), and social tourism attractions have a positive and significant impact on tourist visits [12]. The research in Karangasem which is located in Candi dasa Tourism, showed that the main factors that influence tourist satisfaction are physical factors, namely attraction factors which are reflected by the attraction of natural tourism, cleanliness, in addition to physical factors, non-physical factors, namely security and comfort also contribute to tourist satisfaction [13]. But in this study, it has not been tested how the influence of physical and non-physical factors on tourist satisfaction. Based on the phenomenon that tourist visits, especially in new developed tourist areas, are still low and based on research results, it is important to examine how the physical and non-physical environmental influences on tourist satisfaction. Research objectives are (1) to explain the influence of the physical environment reflected in the availability of hotels/inns, restaurants, marine tourism attractions, transportation facilities, cleanliness, location management, the role of fishermen, information centers, parking lots, toilets to the satisfaction of tourists visiting Amed Beach in Karangasem; (2) to explain the influence of non-physical environment which is reflected by the ability of human resources in communicating, cultural values in the community, and the comfort of the satisfaction of tourists visiting Amed Beach in Karangasem

\subsection{Customer Satisfaction (tourist)}

Every company prioritizes that the goal of the company is to satisfy consumers. This is done to anticipate changes in consumer behavior that occur continuously and more rapidly, because consumers today are more educated and have higher demands. To deal with competition and change in consumer behavior, a consumer-centered company that can provide superior value to them and win the competition. If linked to tourist satisfaction, the key to maintaining tourists is to provide higher tourist satisfaction compared to competitors. Travelers who are satisfied will be willing to return to repeat their purchases and recommend to others to buy.

Physical environmental factors are the environment around the area of tourism. Physical environmental factors in the Amed tourism environment are hotels, restaurants, tourism products, transportation facilities, cleanliness, location management. Non-physical environment covers the cultural aspects and human resource capabilities. The cultural aspect is culture in the form of values. Bali has 66 cultural elements in physical form and values [10]. Culture in the form of values determines attitudes and behavior. Sitiari et al. (2016) found values in the concept of jengah taksu, and culture embodies valid and reliable values that reflect local Balinese culture [11]. The ability of HR is reflected by the ability to 
communicate. Based on the results of research on tourist attraction, natural tourism (natural attraction), tourism attractions (building attraction), cultural tourism attractions (cultural attraction), and social tourism attractions have a positive and significant impact on tourist visits [12]. Research in Karangasem, namely in the direction of Candi dasa Tourism, shows that the main factors that influence tourist satisfaction are physical factors, namely attraction factors which are reflected by the attraction of natural tourism, cleanliness, in addition to physical factors, non-physical factors, namely security and comfort also contribute to tourist satisfaction [13]. Based on the results of previous studies, the following hypotheses can be formulated:

H1 Physical environment has a positive and significant effect on tourist satisfaction H2. Non-physical environment has a positive and significant effect on tourist satisfaction H3. Fisk's environment has more influence on tourist satisfaction than the physical environment.

Based on the type of problem studied, the technique used in this study is quantitative descriptive, where descriptive method is a method of collecting data to test hypotheses or answer questions about the final status of the research subject. The nature of the research is explanatory research that relates to the position of the variables studied and the influence of one variable with another variable. This study was conducted using a survey method, which collects information from the total population.

Data collection was carried out in several stages. The first stage carried out the initial survey, with in-depth interviews related to the existing local phenomena, related to the research plan. Furthermore, they still carried out in-depth interviews followed by means of distributing questionnaire

This study applies a quantitative research design. The design of this study was carried out first by using in-depth interviews since conducting the initial survey and disseminating research questionnaires to the respondents. The results are used to formulate a research hypothesis, so the research hypothesis is tested using quantitative analysis. Inferential analysis technique was used to test hypotheses. The analysis technique used is PLS (Partial Least Square).

\section{Results and Discussion}

\subsection{Respondent Profile}

Amed Beach is one of the coastal tourism in Karangasem Regency. Amed Beach includes tourist attractions that are just developing compared to other places in Karangasem. However, based on the results of research, tourists visiting Amed Beach are more foreigners than locals, meaning that Amed Beach is already well known by foreign tourists. Profile of tourists visiting Amed Beach in 2017 is presented in Table 5.1 as follows:

Table 1. Criteria for Research Respondents at Amed beach in 2017.

\begin{tabular}{llll}
\hline No & Note & Total & Proportion \\
\hline 1 & Age & & \\
& $<\quad 20$ & 5 & 5,7 \\
& $20-30$ & 45 & 51,1
\end{tabular}




$$
\begin{aligned}
& 31-\quad 40 \\
& 41-50 \\
& >\quad 50
\end{aligned}
$$

Total

2

Sex

Male

Female

Total

Education level

Senior High School

Undergraduate

Post graduate

Origin

Domestic

Foreigner

5

Length of Stay

$<1$ week

$>1$ week
100

88

Total

\subsection{Test Results Validity and reliability}

The results of the research instrument test showed that the chronbach alpha coefficient is above 0.50 so that the entire instruments are reliable. Validity test is measured by the correlation coefficient between each indicator score and the total of construct score, and what validity test results are significant if greater than 0.30 . The reliability and validity test results show that all instruments are valid and reliable. The coefficients of the reliability and validity test results are presented in the following table:

Table 2. Validity Test.

\begin{tabular}{llcc}
\hline No & STATEMENTS & & Criteria \\
\hline & Physical Environment & & \\
\hline 1. & Number of hotels/inns available according to needs. & $0,617^{* *}$ & Valid \\
2 & Number of restaurants in accordance with the need & 0,584 & Valid \\
3 & The types of attractions on the Sea that are available are very interesting. & 0,821 & Valid \\
\hline
\end{tabular}




\begin{tabular}{|c|c|c|c|}
\hline 4 & Sufficient Transportation facilities & $0,711^{* *}$ & Valid \\
\hline 5 & Clean Environmental & 0,568 & Valid \\
\hline 6 & Good location arrangement & $0,557^{*}$ & Valid \\
\hline 7 & Fishermen are involved in tourism activities & $0,566^{* *}$ & Valid \\
\hline 8 & Available Information center & $0,, 581^{* *}$ & Valid \\
\hline 9 & Adequate parking space & $0,725^{* *}$ & Valid \\
\hline 10 & Clean toilets / bathrooms are available & $0,649^{*}$ & Valid \\
\hline \multirow[t]{2}{*}{11} & Maintained marine environment & $0,689^{*}$ & Valid \\
\hline & Non-Physical Environment & & \\
\hline 8 & $\begin{array}{l}\text { All officers are able to communicate well especially foreign language } \\
\text { skills. }\end{array}$ & $0,823^{*}$ & Valid \\
\hline 9 & Officers involved have social values such as high empathy & $0,884^{* *}$ & Valid \\
\hline 10 & Officers provide service with courtesy and friendliness & $0,783^{* *}$ & Valid \\
\hline \multirow[t]{2}{*}{11} & Officers served attentively & $0,845^{* *}$ & Valid \\
\hline & Tourist Satisfaction & & \\
\hline 14 & $\begin{array}{l}\text { I am satisfied with all the facilities such as lodging/restaurants, } \\
\text { attractions, etc. that are in line with my expectations }\end{array}$ & $0,813^{* *}$ & Valid \\
\hline 15 & I am able to communicate well with all officers. & $0,794^{* *}$ & Valid \\
\hline 16 & I am satisfied with the service that is in accordance with the wishes. & $0,786^{* *}$ & Valid \\
\hline 17 & I feel comfortable at a tourist location & $0,845^{* *}$ & Valid \\
\hline 18 & I am satisfied to visit Amed beach and will tell my friends. & $0,755^{* *}$ & Valid \\
\hline
\end{tabular}

\begin{tabular}{llll} 
2.3. & \multicolumn{2}{l}{ Reliability Test } & Criteria \\
\hline No & STATEMENTS & Reliable \\
1 & Physical Environment & 0,811 & Reliable \\
2 & Non-Physical Environment & 0,850 & Reliable \\
3 & Tourist Satisfaction & 0,856 & \\
\hline
\end{tabular}

Source: Data processed reliable.

The results of the validity and reliability test showed that all variables are valid and

\subsection{The Result of Analysis}

Table 3. Statistical Test Results.

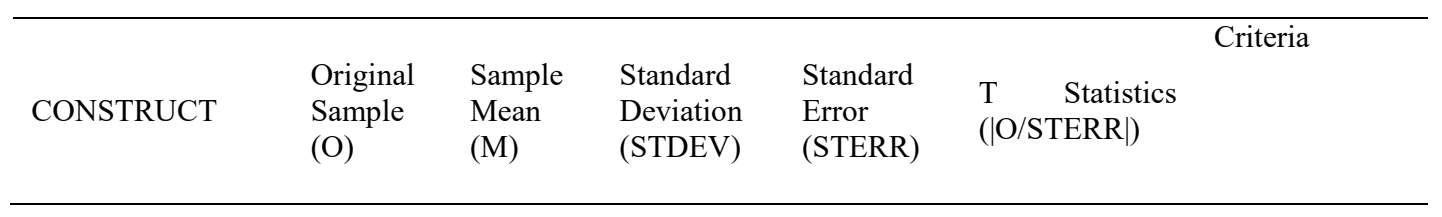




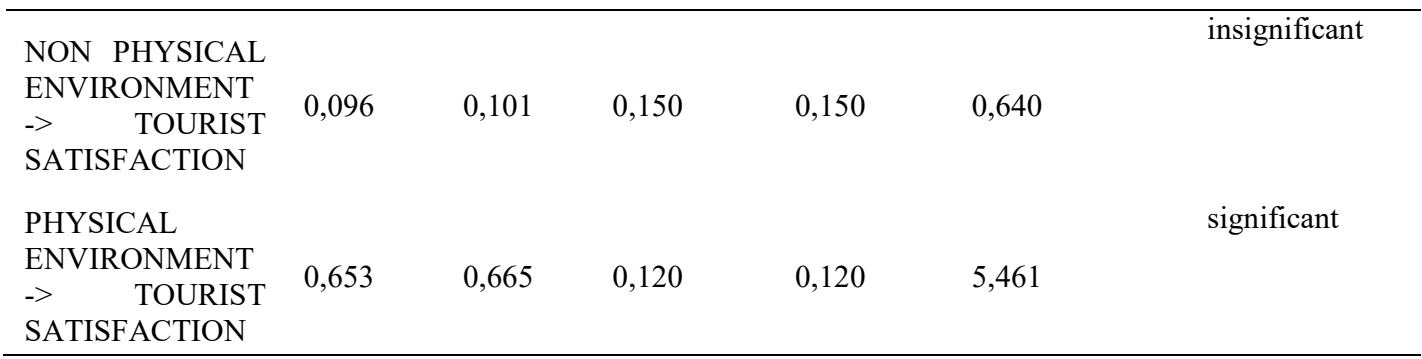

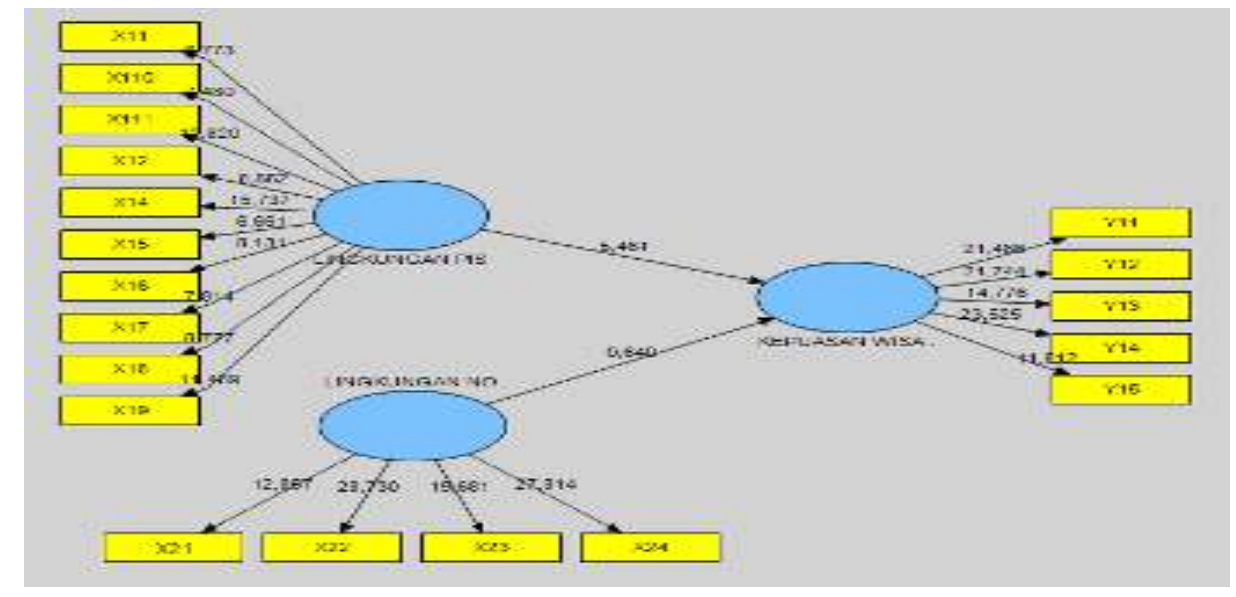

Based on the results of the analysis, the relationship between variables are:

The effect of the physical environment on tourist satisfaction is of 0.653 , and it is significant at the 0.05 level.

The influence of non-physical environment on tourist satisfaction is positive of 0.096 but insignificant.

\section{Discussion}

\subsection{The influence of the physical environment on tourist satisfaction}

The effect of the physical environment on tourist satisfaction has a positive effect of 0.653 , and it is significant at the 0.05 level. This means that the better the physical environment, the more it is satisfactory to the tourists. The most dominant physical environment is reflected by hotel and transportation facilities. This means that tourist satisfaction is increased if the number of hotels is in accordance with the needs of tourists and the availability of transportation facilities. Based on the results of interviews with foreign tourists at Amed beach, transportation facilities, such as limited road directions and parking spaces, need to be improved.

The results of this study support previous research in Bali such as Prawerti's research and Fatmawati's research which find the attractiveness of tourists on Candi dasa beach are physical factors such as attractions, and product quality [13][14]. 


\subsection{The Influence of Non-Physical Environment to Tourists Satisfaction}

The influence of non-physical environment on tourist satisfaction is 0.096 positive but is insignificant. This means that the better the non-physical environment, the tourist satisfaction will increase insignificantly. Non-physical environment is mirrored most strongly served with full empathy, attention, polite, and able to communicate. Based on the results of interviews with the respondent's respondent by the relevant officers, it was friendly and polite, while the ability to communicate is still lacking. The insignificant relationship can be caused by employees who visit Amed beach to feel satisfied and will stay, even more than one day, if there are physical facilities such as lodging and transportation in accordance with the needs, although well served, if the facilities are not met, tourists feel less satisfied.

\section{Conclusion}

The effect of the physical environment on tourist satisfaction has a positive effect of 0.653, and is significant. This means that the better the physical environment, the more satisfaction of tourists

The influence of non-physical environment on the tourist satisfaction is positive but insignificant. This means that the better the non-physical environment, the tourist satisfaction will increase but not significant. The physical environment has more influence on tourist satisfaction. Tourist satisfaction can be improved if the physical environment is more enhanced than non-physical environment. The physical environment is reflected most strongly by the indicators of the type of sea attractions provided and transportation facilities.

Acknowledgements. We would like to address special acknowledgements to God, our family, friends, and also to the editorial boards and publishing team of EAI Publisher for the contribution to the process of publishing this manuscript.

\section{References}

[1] Dutt, C, S., Harvey, W, S and Shaw, G.: The missing voices in the perceptions of tourism: The neglect of expatriates. Tour. Manag. Perspect. Vol. 26. pp. 193-202 (2018)

[2] Richards, G.: Cultural tourism: A review of recent research and trends. J. Hosp. Tour. Manag., Vol. 36. pp. 12-21 (2018)

[3] Guccio, C., Mazza, I., Mignosa, A and Rizzo, I.: A round trip on decentralization in the tourism sector. Ann. Tour. Res. Vol. 72. pp. 140-155 (2018)

[4] Okafor, L. E., Khalid, U and Then, T.: Common unofficial language, development and international tourism. Tour. Manag. Vol. 67. pp. 127-138 (2018)

[5] Huber, D., Milne, S and Hyde, K. F.: Constraints and facilitators for senior tourism. Tour. Manag. Perspect. Vol. 27. pp. 55-67 (2018)

[6] Azam, M., Alam, M, M and Hafeez, M, H.: Effect of tourism on environmental pollution: Further evidence from Malaysia, Singapore and Thailand. J. Clean. Prod. Vol. 190. pp. 330-338 (2018)

[7] Kapera, I.: Sustainable tourism development efforts by local governments in Poland. Sustain. Cities Soc. Vol. 40. pp. 581-588 (2018)

[8] Wan, S, K and Song, H.: Forecasting turning points in tourism growth. Ann. Tour. Res. Vol. 72. pp. 156-167 (2018) 
[9] Bispo, M, de S.: Tourism as practice. Ann. Tour. Res. Vol. 61. pp. 170-179 (2016)

[10] Geriya, Kebudayaan Unggul Inventori Unsur Unggulan sebagai basis Kota Denpasar Kreatif. Denpasar: BAPPEDA. (2010)

[11] Sitiari.: Exploration of Bali's Cultural Values and Entrepreneurial Orientation in Relation to Cooperative Managers In Bali. Eur. J. Bus. Manag. Vol. 8 (2) (2016)

[12] Basiya, H, A, E., \& Rozak.: Faktor-faktor yang mempengaruhi Kepuasan Wisatawan di Kepulauan Tidore [Factors affecting Tourists Satisfaction in the Tidore Islands]. J. Din. Kepariwisataan [Tourism Dyn. Journal]. Vol. 11 (2) (2012)

[13] Prawerti.: Faktor-faktor yang mempengaruhi Penurunan intensitas kunjungan wisatawan di daya tarik wisata Candi dasa, kabupaten karangasem. J. IPTA. Vol. 3 (1) (2015)

[14] Fatmawati.: Edisi Khusus Pemasaran \& Keuangan. J. Ris. Bisnis dan Manaj. Vol. 4 (3). pp. 489-502 (2012) 